\title{
A Post-Consolidation Assessment of Profitability in Nigerian Banks
}

\author{
Oladele, P. 01., Abosede, A. J²., "Akeke, N. I1. \\ ${ }^{1}$ University of Ado-Ekiti, Ado Ekiti. \\ ${ }^{2}$ Olabisi Onabanjo University, Ago-Iwoye. \\ *ninikx2002@yahoo.com
}

\begin{abstract}
Using stochastic frontier technique, this study examined the changes in the profit efficiency of Nigerian banks after the recapitalization exercise of central bank of Nigeria for the period 2006 to 2008. The results showed that the estimated profit efficiency scores for 2006, 2007 and 2008 for troubled banks were $0.79,0.89$ and 0.94 , respectively while corresponding values for healthy banks were $0.47,0.66$ and 0.81 . Average efficiency score of all sampled banks were $0.59,0.75$ and 0.86 for 2006, 2007 and 2008, respectively. The finding implies that profitability is not a good measure of performance.
\end{abstract}

Key words: Post Consolidation, Profit Efficiency, Troubled Banks, Healthy Banks, Performance

\section{Introduction and Literature Review}

In recent years, the structures of financial service industries are changing rapidly; therefore, it is of considerable interest to measure the efficiency of evolving institutions. Creditors and investors use such efficiency evaluations to judge past performance and current position of banks. Due to the growth of competition, management of banks is interested in enhancing efficiency. Bank efficiency studies are of crucial importance for operational purposes (Baten and Kamil, 2010). Many studies have evaluated a wide range aspect of banks efficiency, in different economies. Profit efficiency indicates how well a bank is predicted to perform in terms of profit relative to other banks in the same period for producing the same set of outputs. Profit efficiency is one of the methods of gauging the performance of an organization. Despite the wide agreement on the relevance of profit efficiency analysis, the technical difficulties with the measurement and decomposition of profit inefficiency were the main reasons for the small number of empirical studies on banking profit efficiency. Both parametric and non-parametric techniques have been employed to compute efficiency scores, providing valuable insights not only for academic research but also for regulation and management decisions (Berger and Humphrey, 1997). Nevertheless, while previous research have limited their efficiency analysis to the cost aspect (Baten and Kamil, 2010), recent studies have given more attention to profit efficiency.

Molyneux et al. (1997) underscored the importance of efficiency in banking and point out that higher efficiency can be expected to 'lead to improve financial products and services, a higher volume of funds intermediated, greater and more appropriate innovations, a generally more responsive financial system, and improved risk-taking capabilities if efficiency profit gains are channeled into improved capital adequacy positions. In short, bank efficiency of critical importance to the evaluation of bank performance. Many studies investigating banking profit efficiency adopt a parametric approach following the prominent works of Berger and Mester (1997), DeYoung and Nolle (1996) and DeYoung and Hasan (1998). The few available studies that estimate profit frontier functions report efficiency levels that are much lower than cost efficiency levels, implying that the most important inefficiencies are on the revenue side (Maudos et al., 2002). To our knowledge, few studies, if any, have focused exclusively on the profit efficiency of Nigerian banking sector using stochastic frontier analysis after the consolidation exercise. Available study Sobodu and Akiode (1998), Olaosebikan (2009), Zhao and Murinde (2009) employed the use of Data Envelopment Analysis (DEA) which is a non-parametric technique that compares a producer with the only 'best' producer in estimating relative efficiency. The present study uses the stochastic Frontier Analysis (SFA), which is a parametric or econometric technique to estimate relative efficiency. SFA is a more robust technique than DEA because it has the capacity to deal with large data. In measuring technical efficiency, DEA does not impose any assumptions about production functional form and does not take into account random error hence the efficiency estimates 
may be biased if the production process is largely characterized by stochastic elements. This study intends to evaluate the overall efficiency of Nigerian banks in the context of both productivity and profitability.

\section{Methodology}

Study Sample and Procedure: All the banks that operated in Nigeria during the 2006-2009 were covered. Before the 2005 recapitalization exercise, there were 89 banks in existence and after recapitalization, the banks were consolidated into 25 banks and later reduced to 24 by another merger. The study therefore, focused on the remaining post-consolidated banks in Nigeria. Secondary data were sourced for this study. For the same period from the Annual Reports and Statement of Accounts of selected banks, Central Bank of Nigeria (CBN) and Nigeria Deposit Insurance Corporation (NDIC). Data were also collected from the Statistical Bulletins of CBN and NDIC. Dependent variables of interest to this study included gross earnings, earning assets, total capital, total deposit, interest expenses, loans and advances investments, profit before tax, as well as other operating and personnel expenses. There were three major recapitalization exercises in the Nigerian banking industry during the last ten years. During this process banks were mandated to increase their capital from N500 million to N1billion in 2000; from N1billion to N2billion in 2001; and from N2billion to N25billion in 2005. The 2005 recapitalization exercise reduced the number of banks in the country from 89 to 24 . Out of the 24 banks that operated during the 2006 to 2009 period, 20 were purposively selected and these constituted the sample out of which 13 banks that had consistent data set on the study variables were used for analysis.

Empirical Specification: Profitability was measured by using the transom stochastic profit frontier and independent sample t-test respectively for panel data set of 2006-2008 to compare the level of efficiency of the banks. The stochastic profit frontier model estimate was defined as: The profit frontier model based on a production set consisting of two outputs, namely loans and advances $\left(\mathrm{Y}_{1}\right)$ and investments $\left(\mathrm{Y}_{2}\right)$, and three input prices: the prices of financial capital $(\mathrm{X})$ ), labor $\left(\mathrm{X}_{2}\right)$, and physical capital $\left(\mathrm{X}_{3}\right)$. Where $\mathrm{X}$, was measured as the ratio of interest expenses over deposits, $X_{2}$ was measured as the ratio of personnel expenses over total assets and $\mathrm{X}_{3}$ was measured as the ratio of other operating expenses over fixed assets. To control for risktaking preferences, the ratio of equity over total assets was included as an explanatory variable. The dependent variable in the profit efficiency model was profit before tax. Profit and all outputs were expressed in naira, and input prices in percentages.

Data Analyses: The data collected were processed using FRONTIER 4.1 (Coelli, 1996) estimation 'technique to obtain the maximum likelihood estimates of the parameters in the transom stochastic profit frontier model and to measure the profit efficiency for all the sampled banks. The profit efficiency scores were also measured for both the healthy and troubled banks to compare performance.

\section{Results and Discussion}

Table 1 shows results for estimations of a transom stochastic profit frontier using panel data set for 2006 2008. The significance of the coefficient of $y$ at the $5 \%$ level suggests the presence of one-sided error component. This means that the effect of profit inefficiency is significant; hence, the average profit function is not an adequate representation of the data. The variance ratio, defined by $y={ }^{2} u /{ }^{2} u+{ }_{v}$, is estimated to be $78.8 \%$, meaning that about $79 \%$ of the discrepancies between observed profit and the frontier profit are due to profit inefficiency. In other words, the shortfall of the observed profit from the frontier profit is primarily due to factors like risk management and poor corporate management which are within the control of the sampled banks.

Table 2 shows estimated profit efficiency scores for the 13 sampled banks. The banks were divided into two groups based on their financial viability in order to facilitate comparison between them - troubled and healthy banks. The troubled banks are those banks with extensively high level of non-performing loan attributable to poor corporate governance practices, lax credit administration processes; non-adherence to bank is credit risk management practices. The percentage of non-performing loans to total loans of this bank range from 19 to 48 "reported (Ugwu in Guardian, 2010). The profit efficiency was lowest in 2006 and highest in 2008 for both individual banks and for the various groups of banks. There is a great variation in the 
levels of efficiency ranging is from $12 \%$ to $92 \%$ with a mean of 59\% for all banks in 2006. In 2007 and 2008, the range was $34 \%$ to $96 \%$ and $59 \%$ to $98 \%$, respectively. The average efficiency scores for 2007 and 2008 for all banks were $75 \%$ and $86 \%$, respectively. The average efficiency score was higher for troubled banks than for healthy banks for the three years (2006-2008) under review.

Table 1: Maximum Likelihood Estimates of Translog Stochastic Profit Frontier

\begin{tabular}{|c|c|c|c|}
\hline Variable & Parameter & Coefficient & t-ratio \\
\hline Constant & $\beta_{0}$ & -8.787 & -0.879 \\
\hline LnY & $\beta_{1}$ & 1.200 & 1.729 \\
\hline $\operatorname{LnX}_{1}$ & $\beta_{2}$ & -10.423 & -4.116 \\
\hline $\operatorname{LnX}_{2}$ & $\beta_{3}$ & 7.952 & 2.550 \\
\hline $\ln X_{3}$ & $\beta_{4}$ & 2.273 & 1.332 \\
\hline LnZ & $\beta_{5}$ & -0.519 & -0.203 \\
\hline$(\ln Y)^{2}$ & $\beta_{6}$ & -0.015 & 1.113 \\
\hline$\left(\ln X_{1}\right)^{2}$ & $\beta_{7}$ & -0.974 & -4.278 \\
\hline$\left(\ln X_{2}\right)^{2}$ & $\beta_{8}$ & -1.708 & -4.566 \\
\hline$\left(\ln X_{3}\right)^{2}$ & $\beta_{9}$ & -0.263 & -2.031 \\
\hline$(\ln Z)^{2}$ & $\beta_{10}$ & 1.768 & 2.901 \\
\hline $\ln Y \ln X_{1}$ & $\beta_{11}$ & 0.109 & 1.191 \\
\hline $\ln Y \ln X_{2}$ & $\beta_{12}$ & -0.021 & -0.279 \\
\hline $\ln Y \ln X_{3}$ & $\beta_{13}$ & 0.151 & 1.753 \\
\hline $\ln Y \operatorname{lnZ}$ & $\beta_{14}$ & -0.159 & -1.907 \\
\hline $\ln X_{1} \ln X_{2}$ & $\beta_{15}$ & -0.467 & -1.188 \\
\hline $\ln X_{1} \ln X_{3}$ & $\beta_{16}$ & 1.238 & 2.155 \\
\hline $\ln X_{1} \operatorname{LnZ}$ & $\beta_{17}$ & 1.846 & 4.718 \\
\hline $\operatorname{LnX}_{2} \ln X_{3}$ & $\beta_{18}$ & -0.283 & -0.688 \\
\hline $\operatorname{LnX}_{2} \ln Z$ & $\beta_{19}$ & -1.613 & -2.535 \\
\hline $\operatorname{LnX}_{3} \ln Z$ & $\beta_{20}$ & -1.522 & 2.479 \\
\hline$\sigma^{2}$ & & 0.246 & 0.754 \\
\hline$\Gamma$ & & 0.788 & $2.371^{*}$ \\
\hline $\mathrm{Mu}$ & & -0.880 & -0.538 \\
\hline Eta & & 0.702 & 3.316 \\
\hline
\end{tabular}

Log likelihood function $=11.161$

LR test of one sided error $=14.080$

Where $\mathrm{Y}=$ loans and advances; $\mathrm{Xi}, \mathrm{X}_{2}, \mathrm{X}_{3}$ were defined as prices of financial capital, labor, physical capital respectively and $\mathrm{Z}$ as ratio of equity over total assets.

Source: Data Analysis, 2010

However, the rate of increase in efficiency is higher for healthy banks than for the troubled banks in the sample. The average efficiency score for healthy banks varies from $47 \%$ in 2006 to $81 \%$ in 2008 , while that of troubled banks varies from $79 \%$ in 2006 to $94 \%$ in 2008. The estimated level of profit efficiency scores does not support the classification of banks according to the 2009 special audit of the CBN. This may imply that statistics published by banks in their annual reports do not disclose the correct financial status or soundness of Nigerian banks. According to NDIC (2008) Annual Report, out of the 24 banks in the industry as at the end of 2008, twenty-one (21) were rated sound and/or satisfactory, two marginal and one was rated as unsound. This erroneous classification was also made based on bank returns as at 2008. However, the special audit of 2009 showed that 10 out of the 24 banks were actually at the brink of collapse. 
Table 2: Profit Efficiency Scores of Sampled Banks (2006 - 2008)

\begin{tabular}{lllcc}
\hline S/N & Bank & \multicolumn{3}{c}{ Profit Efficiency Estimates } \\
& & $\mathbf{2 0 0 6}$ & $\mathbf{2 0 0 7}$ & $\mathbf{2 0 0 8}$ \\
\hline 1. & ZENITH & 0.53 & 0.72 & 0.85 \\
2. & SKYE & 0.36 & 0.60 & 0.77 \\
3 & UBA & 0.36 & 0.60 & 0.77 \\
4. & FIRST & 0.76 & 0.87 & 0.93 \\
5. & ACCESS & 0.71 & 0.84 & 0.92 \\
6. & DIAMOND & 0.68 & 0.82 & 0.91 \\
7. & IBTC & 0.24 & 0.49 & 0.70 \\
8. & STERLING & 0.12 & 0.34 & 0.59 \\
9. & INTERCONTINENTAL & 0.61 & 0.78 & 0.88 \\
10. & UNION & 0.76 & 0.87 & 0.93 \\
11. & BANK PHB & 0.81 & 0.90 & 0.95 \\
12 & WEMA & 0.92 & 0.96 & 0.98 \\
13. & AFRIBANK & 0.87 & 0.93 & 0.97 \\
\hline All banks & & 0.59 & 0.75 & 0.86 \\
Healthy & & $0.47^{*}$ & $0.66^{*}$ & $0.81^{*}$ \\
banks & & & & \\
Troubled & & $0.79^{*}$ & $0.89^{*}$ & $0.94^{*}$ \\
banks & & & & \\
\hline
\end{tabular}

* Signifies that the means differ significantly at $5 \%$ level.

Source: Data Analysis 2010

\section{Conclusion}

The stochastic frontier model showed that the estimated profit efficiency scores for 2006, 2007 and 2008 for troubled banks were $0.79,0.89$ and 0.94 , respectively while corresponding values for healthy banks were $0.47,0.66$ and 0.81 . Average efficiency score of all sampled banks were $0.59,0.75$ and 0.86 for 2006, 2007 and 2008 , respectively. The troubled banks recorded significantly higher average efficiency scores for the period under review when compared with healthy banks. The implication of this result is that profitability is not a good measure of performance and this is supported by results of the research carried out by European central bank (2010). The present findings did not support the classification of banks as healthy or troubled by the central bank of Nigeria.

\section{References}

Baten, M. D. \& Kamil, A. A. (2010). Measuring Online Bank profit efficiency: A stochastic frontier analysis. Proceedings of the 6th IMT-GT Conference on Mathematics, Statistics and its Applications (ICMSA2010). University Tunku Abdul Rahman, Kuala Lumpur, Malaysia.

Berger, A. N. \& Humphrey D. B. (1991). The Dominance of Inefficiencies over Scale and Product Mix Economics. Journal of Monetary Economics, 20, 501-20.

Berger, A. N. \& Mester, L. J. (1997). Inside the Black Box: What Explains Differences in the Efficiencies of Financial Institutions? Journal of Banking and Finance, 21(7), 895-947.

Coelli, T. (1996). A Guide to Frontier Version 4.1: A Computer Programme for Frontier Production Function Estimation. CEPA Working Paper 96/08, Department of Econometrics, University of New England, Armidate, Australia.

DeYoung, R. \& Hasan, I. (1998). The performance of De Novo Commercial Banks: A profit efficiency approach. Journal of Banking and Finance, 22, 565-587.

DeYoung, R. \& Nolle, D. E. (1996). Foreign-owned Banks in the United States: Earning market share or buying it. Journal of Money, Credit and Banking, 28, 622-636.

European Central Bank. (2010). Beyond ROE - How to measure Bank Performance. Appendix to the Report on E.U Banking Structures. 
Marton, D. (2003). Development and efficiency of the banking system: A Hungarian Experience. Journal of Banking and Finance, 27(12), 2249-2271.

Maudos, J., Pastor, J., Perez, F. \& Quesada, J. (2002). Cost and profit efficiency in European banks. Journal of International Financial Markets Institutions and Money, 12, 33-58.

Molyneux, P., Altunbas, Y. \& Gardener, E. (1997). Efficiency in European Banking. New York: John Wiley and Sons.

NDIC. (2008). Annual Reports and Statement of Accounts. Nigeria Deposit Insurance Corporation. December 31.

Olaosebikan, S. P. (2009). The causes of bank failure and persistent distress in the Banking Industry. NDIC Quarterly, 13, 15-27.

Sobodu, O. O. \& Akiode, P. O. (1998). Bank privatization and performance; Empirical Evidence from Nigeria. Journal of Banking and Finance, 29 (8 - 9), 2355 - 2379.

Ugwu, E. (2010). Caging loan defaulter: Is the process on. Guardian, Wednesday, June 9. pp 23.

Zhao, T. \& Murinde, V. (2009). Bank Competition, risk taking and productive efficiency: Evidence from Nigeria's banking reform experiment. Stirling Economics Discussions Papers, 2009 -23, Division of Economics, University of Stirling. 